\title{
The Green Technology Innovation Mechanism and Path Selection of Government Subsidy
}

\author{
Songqin $\mathrm{Ye}^{1}$, Xin Guo ${ }^{1, *}$ \\ ${ }^{1}$ School of Finance, Jiangxi Normal University, Nanchang, Jiangxi 330022, China \\ *Corresponding author. Email: guoxin9821@qq.com
}

\begin{abstract}
Chinese economy is achieving the transition from rapid growth to high-quality growth, and green development occupies an important position in the process. Green technology innovation is a necessary condition for green development. Government subsidy, as one of the policy tools that carry the government's will, can affect the green technology innovation behaviour of enterprises. In order to explore the mechanism of government subsidy affecting corporate green technological innovation, this article uses a literature research method to find that the resource attribute and signal attribute of government subsidy jointly promote independent green technological innovation of enterprises, but imperfect government subsidy policies and corporate opportunistic behaviour will weaken the effect of subsidies. Therefore, to improve the efficiency of government subsidy to promote green technological innovation of enterprise, this article recommends that the government optimize the subsidy policy and enterprises make rational use of subsidies to break the "economy-environment" vicious circle and achieve high-quality economic development.
\end{abstract}

Keywords: Government subsidy, green technology innovation, resource attribute, signal attribute, path

selection

\section{INTRODUCTION}

Since Economic Reform and open up, China has made a leap from poverty during the founding period to the world's second largest economy. Economic growth has achieved remarkable results, but behind it, there are serious ecological problems such as waste of resources and environmental destruction. The balance between economic construction and environmental protection has become an obstacle to Chinese sustainable development, and green development is imperative. The 2019 government work report has pointed out that "green development is a necessary condition for building a modern economic system" and required "vigorous promotion of green development." Green technological innovation is the core of green development. The "13th Five-Year Plan" focuses on the "green development concept" and "innovation-driven" development strategy. But green technology innovation has dual externalities. Market power alone cannot promote independent green technological innovation of enterprises, which requires government actions to guide them. As one of the policy tools that carry the government's will, government subsidy can effectively improve the lack of green technological innovation under the market economy system, increase the enthusiasm of enterprises for green technological innovation, and promote the coordinated development of ecology and economy.

\section{GREEN TECHNOLOGY INNOVATION}

\subsection{Definition and Classification}

Green technology innovation is a solution proposed to alleviate the contradiction between economic construction and environmental protection. The European Commission clearly defines that green technological innovation is a general term for environmentally friendly technologies, processes and products that reduce energy consumption, reduce or even avoid environmental pollution, and ensure that ecological negative effects are minimized ${ }^{[1]}$. The Organization for Economic Cooperation and Development (OECD) divides green technological innovation into green process innovation and green product innovation ${ }^{[2]}$. Among them, green process innovation tends to update production equipment and recycle industrial waste in the direction of energy conservation and emission reduction; green product innovation emphasizes the need for energy conservation, emission reduction, and pollution reduction in the entire process from $\mathrm{R} \& \mathrm{D}$ to large-scale production, and the finished product has a low environmental load of green products. 


\subsection{Double-externality}

Compared with traditional technological innovation, green technological innovation has dual externalities. One is the positive externality of technological innovation knowledge spillover. Technological innovation is essentially a kind of knowledge product, with the characteristics of a public product. The main reasons are: (1)the publication of patent information. Part of the patent information needs to be publicly disclosed for patent applications; (2)the existence of upstream suppliers and downstream markets. During the research and development process, companies need to purchase corresponding materials and equipment from upstream suppliers, and supply new products to the downstream market after successful research and development; (3)the flow of technical staff. Technicians are familiar with corporate R\&D information, and the flow of technical staff between enterprises increases the possibility of patent information leakage. Competition agreements cannot prevent such situations. The positive externalities of technological innovation allow competing companies to "free ride". The personal benefits of $R \& D$ activities are less than social benefits, the enthusiasm of corporate innovation is weakened, and the R\&D competition between companies falls into the "waiting game" dilemma ${ }^{[3]}$.

The second is negative externality related to environmental pollution, which is the unique externality of green technological innovation. Green technological innovation adheres to the concept of environmental protection. Neoclassical economics believes that environmental problems are caused by externalities, and the cost of companies destroying the environment is not included in their own costs, but will increase social costs and increase pressure on the public ${ }^{[4]}$. Environmental destruction is in line with the enterprise's self-interest, which leads to weak corporate green development willingness and even excessive pollution. To sum up, whether there is a path dependence on the green technology innovation of enterprises. Market regulation alone cannot allow enterprises to independently carry out green technological innovation ${ }^{[5]}$, and appropriate government subsidy policies are needed to guide enterprise innovation behaviour.

\section{THE MECHANISM OF GOVERNMENT SUBSIDY TO PROMOTE GREEN TECHNOLOGICAL INNOVATION}

\subsection{Resource Attributes of Government Subsidies and Green Technology Innovation}

Government subsidy has resource attribute and can bring financial support to enterprise, which is mainly reflected in alleviating the financial constraints of enterprise innovation, reducing the burden imposed on enterprises by environmental regulations, reducing enterprise $R \& D$ risks, and promoting enterprise to innovate in the green direction.

On the one hand, government subsidies ease the cost pressure of enterprises' green innovation inputs. China has issued environmental regulations and policies to standardize corporate behaviour in order to promote the green development of enterprises. But environmental regulations will increase the burden on enterprises, and green innovation funds will be squeezed out to the non-productive pollution control link. This phenomenon is most prominent among heavily polluting enterprises ${ }^{[6]}$. The increase of non-productive pollution prevention and control costs hinders the innovation of enterprises in the green direction. In addition, innovative projects require companies to continuously invest large amounts of capital from start to finish, and require higher capital chains for companies. Especially when the cost of non-productive pollution prevention and control is lower than the cost of green R\&D, the company's enthusiasm for green technology innovation will be further weakened. Government subsidies will reduce the R\&D costs of enterprises and make enterprises continue to invest in green technological innovation.

On the other hand, government subsidy reduces the risk of enterprises' green innovation investment. Green innovation activities are highly risky. It is difficult to obtain research and development results, and market promotion is limited by technology and cost requirements. Green technology innovation has a positive externality of knowledge spillover, and the social benefits of new green technologies are greater than the benefits of enterprises themselves. Therefore, companies tend to "free ride", and they fall into the "waiting game" dilemma of green technology innovation. It leads to market failure, which in turn leads to insufficient investment in green technology innovation under the distortion of resource allocation [7]. Market power alone cannot achieve independent green technological innovation by enterprises. According to the theory of government intervention, relevant government policies can correct the distortion of resource allocation caused by market failures and realize the optimal allocation of resources. By giving capital support to enterprises, government subsidy can effectively make up for the social welfare losses caused by green technological innovation, reduce enterprise R\&D risks, and encourage enterprises to spontaneously increase investment in green innovation.

\subsection{Signal Attributes of Government Subsidies and Green Technology Innovation}

In addition to enabling enterprises to obtain green innovation resources, government subsidy also has signal transmission properties, which can ease the external financing constraints of corporate innovation funds, obtain support from stakeholders, and create a good environment for corporate green technological innovation. 
On the one hand, government subsidy alleviates external financing constraints and solves the problem of insufficient funds for corporate green innovation. The green $R \& D$ process is highly uncertain and requires companies to continuously invest large amounts of funds to ensure the orderly progress of R\&D activities. However, the internal funds of the enterprise are limited, and the daily production and operation activities are expensive. The company cannot support the capital expenditure of green research and development activities alone, and the company needs to raise funds from outside. There is information asymmetry between companies and external investors, investors are unable to fully grasp the company's green development, and their willingness to invest is not strong. The government's measures to subsidize the company indicate that the company meets the current environmental regulations and convey to the outside world that the government recognizes and supports the company. The release of this good news can be regarded as an implicit credit guarantee for enterprises. In addition, before government subsidies, the company will examine the basic situation of the company, and after strict screening, determine whether to issue subsidies to the company. After the subsidy is issued, the company will be supervised and the use of subsidies will be evaluated ${ }^{[8]}$. Investing in subsidized companies can not only reduce the cost of investigating companies, but also reduce corporate moral risks, and investors' willingness to invest is strengthened. It can be seen that government subsidies send positive signals to potential investors in the market and increase external investment by enterprises, so that enterprises can have sufficient funds to invest in green innovation, thereby promoting the progress of green technological innovation. On the other hand, government subsidy can help companies introduce high-tech talents, gain support from partners, and improve the efficiency of green innovation. The choice of employment for high-tech talents and the degree of support provided by partners to the company will all take into account the development prospects of the company. In the case of information asymmetry, the favourable information that companies receive government subsidies has become an important basis for judging the healthy development of the company, making high-tech talents prefer to choose the company, and the partners will cooperate with the company's actions to provide support for green innovation. In addition, government subsidy is policy-oriented. The higher the development direction of an enterprise conforms to the government's will, the more government subsidies will be obtained. The 19th National Congress of the Communist Party of China pointed out that pollution prevention and control is one of the three tough battles for building a moderately prosperous society in an all-round way, and promoting the green development of enterprises is a necessary task for the government. The green technology innovation of enterprises caters to the government's needs, and the government will support this type of enterprise. Therefore, in order to obtain continuous government subsidies, companies will have a strong willingness to invest in green innovation and promote their green technological innovation output.

\section{OBSTACLES TO GOVERNMENT SUBSIDY PROMOTING GREEN TECHNOLOGY INNOVATION}

Huayuan Energy News reported that the thermal power industry receives huge government subsidies every year, but the pollution situation has not improved or even worsened. The willingness of government subsidies is to promote green technological innovation of enterprises, but the effect is limited. The main reasons are:

Information asymmetry between government and enterprises. The government cannot accurately grasp the information of all companies applying for subsidies, so it is unable to fully identify companies with real green technological innovation capabilities, and some companies may falsify their declaration information to defraud government subsidies for their own interests, so that government subsidies cannot promote corporate green Innovation.

Insufficient government supervision. Government depart-ments have public functions and need to promote economic growth and maintain social stability at the same time. The supervision of the use of corporate funds may be insufficient. Some companies will take advantage of this vacancy and use government subsidies for other purposes, and the real effect of subsidies is far from expected.

Government subsidies are not suitable for enterprises. Government subsidies are divided into direct subsidies and indirect subsidies. Direct subsidy means that the government directly allocates funds to subsidized enterprises, and the subsidy is relatively large; indirect subsidy is the use of tax incentives and other methods to make enterprises profit, and the policy is highly controllable. Direct subsidies and indirect subsidies are used for enterprises based on different mechanisms and are not universal. Therefore, in order to give full play to the promotion effect of government subsidies on green technological innovation, the government should analyse the actual situation of enterprises to determine the form of subsidy payment. However, in practice, the government may only decide the form of subsidy to enterprises according to its own wishes, and has not fully examined the actual situation of different enterprises. This reduces the positive effect of subsidies on the green $R \& D$ activities of enterprises, and the effectiveness of corporate green technological innovation is affected. 


\section{PATH SELECTION FOR GOVERNMENT SUBSIDY TO PROMOTE GREEN TECHNOLOGICAL INNOVATION OF ENTERPRISES}

\subsection{Government Level: to Improve Government Subsidy Policies and Optimize the Environment for Green Innovation}

Strengthen the review mechanism for enterprise subsidy applications. In order to prevent enterprises from fraudulently obtaining or embezzling subsidies, the government must not only strictly examine the company's existing green achievements, but also agree on green technological innovation behaviours after the company's subsidies. If the company fails to meet the requirements for green results within the agreed period, it will be punished to a certain extent. The financial status of enterprises also needs to be closely monitored.

When granting subsidies, fully consider the situation of the enterprise and focus on the organic combination of different forms of government subsidies. Government grants should fully examine the internal and external environments of various enterprises, such as enterprise scale, production level, financing environment, economic development in the region, and pay attention to the complementarity and difference between direct funding and indirect funding in guiding enterprises' green innovation. The government should provide enterprises with appropriate forms of subsidies in a targeted manner to weaken the rent-seeking motivation of enterprises in order to achieve the best effect of subsidies.

Improve the subsidy supervision system and information disclosure mechanism. The government inspects regularly or irregularly the use of funds and subsequent results of subsidized enterprises, and the process should be open and transparent. What's more, establish a set of corporate green technology innovation performance evaluation systems that comprehensively should consider environmental efficiency, economic efficiency and social efficiency.

\subsection{Enterprise Level: Rational Use of Government Subsidy to Strengthen the Awareness of Green Development}

First of all, companies should strengthen their overall green awareness and establish a sound subsidy use supervision mechanism internally. Companies should take measures to strengthen the green awareness of their employees and incorporate green development awareness into their production and operations. Secondly, companies should set up a special monitoring team to supervise the use of subsidies by relevant departments and set up corresponding punishment mechanisms to prevent improper behaviour and ensure that subsidies for green technology innovation will not be misappropriated. Finally, companies regularly publicize the acquisition and use of corporate subsidies to the outside world, which can convey positive signals to the outside world, shape a good image, and gather resources for green research and development.

\section{CONCLUSION}

In summary, government subsidies have dual attributes of resources and signals. The subsidy effectively promotes the independent green research and development of enterprises by reducing the cost pressure of enterprises' green investment, reducing the risk of green research and development, alleviating the external financing constraints of research and development, and providing support for stakeholders. However, problems such as information asymmetry, inappropriate subsidy methods, and insufficient government supervision limit the promotion of subsidies. Therefore, the government and enterprises need to deeply understand the importance of subsidies and take relevant measures to maximize the efficiency of subsidies to promote green technological innovation, so that the economy can develop green and successfully build a modern economic system.

\section{ACKNOWLEDGMENT}

This work was supported by Postgraduate Innovation Fund Project of Jiangxi Provincial Department of Education: Research on the impact of environmental protection subsidy on corporate environmental governance performance and its Mechanism_-Based on the experience of heavy-polluting enterprises (YC2020-S143).

\section{REFERENCES}

[1] Zhang Zhiqin. Analysis of the status quo and prospects of the EU's green economy[J]. Global Science and Technology Economic Outlook, 2013, 28(1): 50-57. (In Chinese)

[2] OECD. The measurement of scientific and technical activities [M] 3rd ed. Paris: OECD Publishing, 2005.

[3] Zúñiga-Vicente J. Á., Alonso-Borrego C., Forcadell F.J., et al. Assessing the Effect of Public Subsidies on Firm R\&D Investment: A survey [J]. Journal of Economic Surveys, 2014, 28(3):36-67.

[4] Liu Jinru, Zeng Xianfeng, Zeng Qian. The impact of environmental regulations and government innovation subsidies on enterprise green product innovation [J]. 
Economic and Management Research, 2019, 40(6): 106-118. (In Chinese)

[5] Zhang Cheng, Lu Yang, Guo Lu, Yu Tongshen. The intensity of environmental regulation and the progress of production technology [J]. Economic Research, 2011, 46(2): 113-124. (In Chinese)

[6] Guo Jie, Yang Licheng. The impact of environmental regulations and government $R \& D$ funding on green technology innovation: An empirical analysis based on provincial data in Mainland China [J]. Science and Technology Progress and Policy, 2020, 37(10): 37-44. (In Chinese)

[7] Li Xuhui, Zheng Lilin. Research on the effect of government subsidies on enterprise innovation investment behavior under adverse selection behavior[J]. Research in Scientific Management, 2019, (3): 109-114. (In Chinese)

[8] Wu Jian, Tian Zhilong, Long Xiaofeng, Xiong Qi. The impact of government subsidies on enterprise innovation in strategic emerging industries [J]. Studies in Science of Science, 2018, 36(1): 158-166. (In Chinese) 